\title{
Gelinada Grinczenko
}

[Charków, Ukraina]

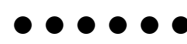

\section{Historia mówiona na Ukrainie: ludzie, tematy, fakty*}

Wrocławski Rocznik

Podczas gdy historia mówiona jako praktyka badawcza na Zachodzie liczy ponad pół wieku, we współczesnej Ukrainie, jak również i w pozostałych krajach obszaru postsowieckiego zaczęła ona zyskiwać na popularności dopiero z początkiem lat 9o. XX wieku. Tu jednak warto podkreślić, że już od dwóch dekad historia mówiona na Ukrainie stała się nie tylko popularną metodą pracy w terenie, praktykowaną przez badaczy reprezentujących szeroki wachlarz dyscyplin naukowych (społecznych i humanistycznych), lecz także pożądanym źródłem wiedzy, wykorzystywanym w analizie zarówno procesów społecznych, jak i indywidualnych oraz intymnych doświadczeń przeszłości.

* Niniejszy tekst jest rozszerzoną wersją części napisanej przez autorkę w artykule zbiorowym dotyczącym sytuacji historii mówionej na Ukrainie, Białorusi i w Rosji. Zob.: G.G. Grìnčenko, İ.V. Rebrova, İ.M. Romanova, Usna istorîâ v postradânśkih doslidnickih praktikah (na prikladi sučasnih Bilorusi, Rosï ta Ukrä̈ni), „Ukraïnśkij ìstoričnij žurnal” 2012, No 4, s. 172-187. Zob. także białoruski tekst: G. Grynčanka, Ì. Rabrova, Ì. Ramanava, Vusnaâ gistoryâ ŭ postsaveckìh dasledčyckìh praktykah Belarusi, Rasiì i Ukraìny, „Belaruskì gìstaryčny časopìs” 2012, No 7, s. 39-48. Tekst umieszczony we „Wrocławskim Roczniku Historii Mówionej” został uzgodniony ze współautorkami wyżej wymienionych publikacji i nie narusza ich praw autorskich. 
Przede wszystkim stało się to możliwe dzięki odejściu w ostatnim dziesięcioleciu minionego stulecia od metodologii badań naukowych charakterystycznych dla sowieckiej ideologii kolektywistycznej. Zmiana ta przeniosła punkt ciężkości w badaniach historycznych $\mathrm{z}$ doświadczenia zbiorowego na jednostkę - jako aktywnego aktora historii, i na doświadczenie prywatne - jako podstawową społeczno-kulturową wartość społeczeństwa. Ogromną rolę w upowszechnianiu metody historii mówionej odegrały wówczas także inicjatywy podejmowane w przestrzeni publicznej i naukowej, polegające na „oswojeniu” niepopularnych, marginalizowanych lub zabronionych tematów w ramach uzupełniania tzw. białych plam w dziejach poszczególnych narodów. W końcu też intensywnemu rozwojowi historii mówionej na Ukrainie od samego początku jej istnienia sprzyjało i nadal sprzyja wsparcie i akceptacja ze strony społeczności akademickiej, wolność w wyborze tematów badań oraz różnorodność sposobów propagowania wyników tychże badań. Publikowane w ciągu ostatnich dwudziestu lat artykuły, wspomnienia i pierwsze opracowania monograficzne z wykorzystaniem historii mówionej zajęły czołowe miejsce we współczesnej historiografii ukraińskiej. Natomiast projekty, polegające na spisywaniu wspomnień, znalazły swoje miejsce w praktykach zarówno naukowych, jak i edukacyjnych, popularyzatorskich oraz popularnonaukowych nastawionych na poznanie różnorodnej przeszłości kraju.

W niniejszym artykule postawiono za zadanie scharakteryzować etapy rozwoju historii mówionej na Ukrainie oraz określić jej cechy szczególne, przeanalizować zakres tematyczny istniejących badań w historii mówionej i na tej podstawie ukazać dynamikę instytucjonalizacji tego nurtu w całości. Naświetlając te kwestie, warto podkreślić, że w tekście tym historia mówiona rozumiana jest zarówno jako metoda pozyskiwania wspomnień, opowieści czy narracji biograficznych, jak i przytoczone w badaniach naukowych wyniki dokonanej analizy tychże źródeł narracyjnych, a także inne nienaukowe formy wprowadzenia spisanych świadectw do obiegu publicznego przede wszystkim w postaci stron internetowych oraz filmów.

W moim przekonaniu na Ukrainie, podobnie jak w Rosji i na Białorusi, historia mówiona przeszła przez dwa zasadnicze etapy rozwoju. Każdy z nich charakteryzował się określonymi priorytetami tematycznymi, sposobem podejścia do źródła, ograniczeniami w ramach poszczególnych dyscyplin, a także miejscem, które historia mówiona zajmowała w hierarchii akademickiej w ogóle. Pierwszy etap obejmował lata 9o. XX wieku, gdy na tle ogólnego kryzysu w naukach społecznych i humanistycz- 
nych trwało poszukiwanie nowych tematów i podejść badawczych, w tym ukształtowanie się zainteresowania metodą historii mówionej. Na tym etapie kluczową rolę w zwróceniu uwagi społeczności akademickiej na historię mówioną jako metodę i źródło badań odegrała międzynarodowa konferencja z udziałem licznych zachodnioeuropejskich badaczy. Konferencja ta odbyła się pod tytułem „Metodologia i metody historii mówionej - historia życia w badaniach socjologicznych” ("Metodologìâ ì metodi usnoï ìstorìi - ìstorïi žittâ v socìologìčnih doslìdžennâh"), która odbyła się we wrześniu 1994 r. we Lwowie w Instytucie Historii Cerkwi (Ìnstitut ìstorïi cerkvi). W konferencji uczestniczyło 64, badaczy z 17 krajów Europy i obu Ameryk. Wśród przybyłych znaleźli się uznani specjaliści, tacy jak: pomysłodawca i dyrektor Instytutu Historii i Biografii Uniwersytetu w Hagen Alexander von Plato (Niemcy), sekretarz Brytyjskiego Towarzystwa Historii Mówionej Rob Perks (Wielka Brytania), profesor Uniwersytetu Rzymskiego Alessandro Portelli (Włochy) i wielu innych. Materiały z konferencji niestety nie ukazały się drukiem, jednakże część wystąpień konferencyjnych niektórzy uczestnicy z czasem publikowali w innych wydawnictwach zbiorowych lub jako części monografii zbiorowych. Tu jako przykład warto podać słynny i przełomowy tekst Alessandro Portelli'ego Historia mówiona jako gatunek, który został opublikowany jako rozdział w publikacji zbiorowej ${ }^{1}$, a z czasem doczekał się przedruku w zbiorze artykułów pt. Narracja i gatunek ${ }^{2}$.

Konferencja ta, jak również i organizowane później warsztaty i letnie szkoły z historii mówionej, odegrały, z jednej strony, ogromną rolę w popularyzacji metody historii mówionej, z drugiej zaś - w ukierunkowaniu badaczy ukraińskich na zachodnie standardy pracy akademickiej w dziedzinie historii mówionej. Właśnie od tego momentu w ramach przygotowania i przeprowadzenia projektów z historii mówionej, a następnie analizy wyników badań, zaczęto na całej przestrzeni postsowieckiej twórczo wykorzystywać (uwzględniające konteksty indywidualne danej zbiorowości) teoretyczne, metodologiczne i etyczne wzorce badawcze w zakresie historii mówionej, wypracowane już przez

1 A. Portelli, Oral History as Genre, [w:] Battle of Valle Giulia. Oral History and the Art of Dialogue, Wisconsin 1997, s. 3-23.

2 Idem, Oral History as Genre, [w:] Narrative and Genre, ed. M. Chamberlain, P. Thompson, London-New York 1998, s. 23-45. 
zachodnich badaczy. W pewnym stopniu można tu mówić o przemożnym wpływie i „hegemonii intelektualnej szeroko pojętego Zachodu” na profesjonalnej niwie historii mówionej w krajach byłego Związku Sowieckiego. Jednakże warto pamiętać również o innej tendencji, polegającej na ukierunkowaniu historii mówionej na metodologię sięgającą swym korzeniem epistemologicznym do tradycyjnej, klasycznej etnografii uprawianej z końcem XIX w. ${ }^{3}$ Co więcej, to właśnie w wyniku ewolucji stricte etnograficznych badań o charakterze terenowym idącym w kierunku historii mówionej, przyczyniło się do utworzenia szeregu laboratoriów badawczych z historii mówionej na wielu uczelniach wyższych. Jako przykład warto podać losy Zaporoskiego Naukowego Towarzystwa im. Jakowa Nowićkiego (Zaporìżke naukove tovaristvo ìm. Â. Nović kogo). W 1999 r. członkowie Towarzystwa oraz uczestnicy z ramienia zaporoskiego oddziału Instytutu Archeologii Ukraińskiej i Źródłoznawstwa im. Mychajły Hruszewśkiego Narodowej Akademii Nauk Ukrainy (İnstitut ukraïnś koï arheografïi ì džereloznavstva ìm. M.S. Gruševś kogo NAN Ukraïni) i Zaporoskiego Uniwersytetu Narodowego zainicjowali cykl wypraw terenowych, których celem było spisanie historii mówionych na wsiach w obwodzie zaporoskim, dniepropietrowskim, donieckim, chersońskim, mikołajowskim, odeskim, kirowohradskim, a także na terenie Autonomicznej Republiki Krymu. Na chwilę obecną uczestnicy tych wypraw spisali narracje ponad 5 tysięcy osób. Towarzystwu natomiast udało się opublikować ponad 10 tomów w serii pt.: Historia mówiona stepowej Ukrainy.

Wśród powstających w latach 9o. ubiegłego wieku centrów i ośrodków, które od początku swojego istnienia wyznaczyły jako profil działalności badania w duchu historii mówionej, warto wymienić: Instytut Historii Cerkwi, mający charakter wirtualnego muzeum, który w roku 1992 rozpoczął projekt badawczy połączony ze stworzeniem strony internetowej pt. „Obraz siły ducha - żywa historia podziemnego życia Ukraińskiej Grekokatolickiej Cerkwi 1946-1989 r.” („Obraz sili duhu. Živa ìstorìâ pìdpìlnogo žittâ Ukraïnśkoï Greko-Katolićkoï Cerkvi 1946-1989 rr.”) ${ }^{4}$. Do dzisiaj projekt ten pozostaje nadal największym i najbardziej owocnym projektem historii mó-

3 Usna istoriâ. Teoriâ ta praktika, upor. A. Bojko, S. Bìlìvnenko, Û. Golovko [et al.], Zaporìžžâ 2008.

4 http://www.ichistory.org/ukrsite/pages/projects1.html (dostęp: 28 IV 2013). 
wionej na Ukrainie. Badacze postawili sobie za zadanie dokonać „szeroko zakrojonych badań i analizy krytycznej zgromadzonych świadectw o życiu religijnym ukraińskich grekokatolików w podziemiu”. W ramach projektu zgromadzono już ponad 1900 wywiadów, nagranych i zdigitalizowanych na ponad 3 tysiącach kaset. Archiwum projektu liczy ponad 700 fotokopii dokumentów archiwalnych, pochodzących z wielu archiwów ukraińskich i prywatnych kolekcji. Archiwum fotograficzne natomiast liczy ponad 5 tysięcy zdjęć. Na podstawie zgromadzonego w trakcie badań terenowych materiału stworzono stałą ekspozycję pt. „Cerkiew w katakumbach” („Katakombna cerkva”) w Instytucie Historii Cerkwi. Obecnie placówka ta szczyci się największym doświadczeniem w gromadzeniu i dokumentacji historii mówionych na Ukrainie.

Pierwsza praca na Ukrainie, pisana w duchu historii mówionej, to wydana w 1999 r. monografia amerykańskiego badacza Williama Nolla pt. Transformacja społeczeństwa obywatelskiego. Historia mówiona ukraińskiej kultury wiejskiej lat 20.-30. ${ }^{5}$ Monografia bazuje na wynikach projektu realizowanego w latach 1993-1995, w trakcie którego spisano narracje ponad 400 mieszkańców wsi na środkowej i wschodniej Ukrainie. Osoby te doświadczyły tragedii kolektywizacji i Wielkiego Głodu.

W ten sposób, w trakcie pierwszego, w pewnym sensie przygotowawczego, etapu rozwoju historii mówionej na Ukrainie, skupiono się głównie na poszukiwaniu inspiracji metodologicznych i ustalaniu priorytetów tematycznych do dalszych badań. Testowano różne formy organizacji pracy, stworzono podstawy do dalszej owocnej współpracy ze specjalistami $\mathrm{z}$ innych krajów, gromadzono doświadczenia $\mathrm{w}$ zakresie popularyzacji wyników badań oraz nabywano doświadczenia praktycznego w zakresie wprowadzania do obiegu publicznego uzyskanych rezultatów za pomocą nowych form rozpowszechniania.

Możliwości prezentacji wyników badań, dotychczas ograniczające się do publikacji autorskich monografii albo zbiorów wspomnień, zostały poszerzone o różnego rodzaju wystawy, filmy dokumentalne, słuchowiska radiowe, projekty internetowe, performanse i wiele innych form. Był to przełom zapoczątkowujący kolejny etap w rozwoju historii mówionej na Ukrainie, który trwa od początku XXI stulecia. Wśród nowych form

5 W. Noll, Transformaciâ gromadâns'kogo suspil'stva. Usna istorîa ukrä̈ns'kö̈ selâns'koï kul'turi 1920-3o rokiv, Kiïv 1999. 
prezentowania należy wymienić projekt internetowy pt. „Historia mówiona niepodległej Ukrainy 1988-1991” („Usna ìstorìâ nezaležnoï Ukraïni 1988-1991"), który proponuje internautom pełne wersje wywiadów wideo wraz z transkrypcjami, nagranych z 69 działaczami politycznymi, dysydentami, dyplomatami, dziennikarzami i działaczami społeczno-religijnymi, osobami duchownymi, przedsiębiorcami i uczonymi, którzy brali udział lub byli świadkami procesu powstawania niepodległej Ukrainy ${ }^{6}$. Jak wynika z wprowadzenia na stronie domowej projektu, miał on cele wyłącznie akademickie i badawcze; celem jego było bowiem zapoczątkowanie „badania ruchów narodowych i organizacji społecznych, które istniały na Ukrainie w latach 1988-1989, objął on również tematycznie wydarzenia związane z pertraktacjami prowadzącymi ostatecznie do podpisania nowego porozumienia pomiędzy byłymi republikami związkowymi latem 1991 r., próbami sierpniowego zamachu stanu w sierpniu 1991 r., wypromowaniem Borysa Jelcyna w Moskwie oraz pogłębieniem aspiracji narodowych w poszczególnych republikach i ich kulminacji w postaci ogólnoukraińskiego referendum w sprawie niepodległości z grudnia 1991 r. oraz uznania niepodległego państwa ukraińskiego na arenie międzynarodowej”. Cele edukacyjne i popularyzatorskie realizował również projekt „Muzeum pamięci reżimów totalitarnych «Terytorium terroru» we Lwowie” („Memorìaĺnij muzej totalìtarnih reži mìv «Teritorìa Teroru» u Lvovì). Zbiory muzeum stanowią wspomnienia świadków i ofiar totalitaryzmów. Wywiady utrwalone na nośnikach wideo, jak to zostało podkreślone na stronie muzeum, są wykorzystywane w celu tworzenia interaktywnych ekspozycji oraz produkcji filmów dokumentalnych. Wykorzystano je m.in. do filmu Złoty wrzesień. Kronika Galicji 1939-1941 (Lwów 2010) (Zolotij vereseń. Hronika Galičini 1939-1941).

Ogólnie rzecz ujmując, filmy dokumentalne, oparte na nagraniach świadków historii, nie tylko zaznajamiają szeroki ogół odbiorców z doświadczeniem współobywateli oraz ich „opowieścią z pierwszej ręki”, lecz także sprzyjają poszerzeniu zaufania do tego rodzaju materiałów dokumentacyjnych, kształtowaniu się szacunku do drugiej osoby i szerzeniu się postaw tolerancyjnych w społeczeństwie. Przykładowo ogromny rezonans społeczny wywołała projekcja filmu Nazwij swoje

http://oralhistory.org.ua (dostęp: 28 IV 2013).

http://www.territoryterror.org.ua/uk/projects/living-history (dostęp: 28 IV 2013). 
imię (Nazvi svoe ì́ $\hat{a}$ ) w reżyserii Serhija Bukowśkiego, nakręconego w 2006 r. przez Instytut Historii Wizualnej i Oświaty Fundacji Shoah w Kalifornii (USC Shoah Fundation The Institute for Visual History and Education). Jest to narracja wizualna utkana z opowieści osób, które doświadczyły Holocaustu. Film został sfinansowany z pieniędzy amerykańskiego reżysera Stevena Spielberga oraz ukraińskiego polityka i biznesmena Wiktora Pinczuka ${ }^{8}$. W opisie filmu na stronie internetowej PinshukArtCentre czytamy: „film zaprasza do dramatycznej wędrówki przez przeszłość i współczesność. Reżyser wraz z trzema asystentkami, studentkami dziennikarstwa z Ukrainy, a następnie widz, poznają świadectwa Żydów, którzy doświadczyli tragedii i wymknęli się śmierci, oraz tych, którzy, nie zważając na śmiertelne niebezpieczeństwo, wykazali się niebywałą odwagą, ratując przyjaciół czy sąsiadów narodowości żydowskiej w czasach Holocaustu. Bohaterowie filmu dzielą się co do najmniejszych szczegółów swoim doświadczeniem, widz natomiast od czasu do czasu ma możliwość odnieść się do współczesności i zobaczyć okropne następstwa okupacji hitlerowskiej, które do tej pory odciskają piętno na społeczeństwie ukraińskim"

Mówiąc o początkach drugiego etapu w rozwoju historii mówionej na Ukrainie, warto zauważyć, że jego cechą charakterystyczną stał się coraz to bardziej rzucający się w oczy podział na „zawodowców” i „miłośników”. Podział ten wyraźnie się określił już w połowie pierwszego dziesięciolecia XXI w. W tym bowiem czasie dokumentacja opowieści świadków historii odbywała się wręcz na masową skalę przez przedstawicieli środowisk akademickich, w tym studentów oraz uczniów szkół średnich, członków różnego rodzaju towarzystw i organizacji non-profit, dziennikarzy itp. Sposób pracy w terenie całej tej niejednorodnej grupy jest oceniany jako praktykowanie historii mówionej. Ze względu na masowy charakter inicjatyw zbierania świadectw, w zasadzie równolegle rozwijały się dwa zupełnie odmienne sposoby uprawiania historii mówionej: pierwszy przez środowisko akademików-intelektualistów, a drugi - całkowicie amatorski. Przy czym ten ostatni w dużej mierze historię mówioną przypomina tylko z nazwy, gdyż w rzeczywistości jest

8 Informację o filmie w językach ukraińskim, angielskim i rosyjskim zob. na: http:// spellyourname.org/ukr/main.php (dostęp: 28 IV 2013).

9 http://pinchukartcentre.org/ua/news/22658 (dostęp: 28 IV 2013). 
to szyld zasłaniający różnego rodzaju inicjatywy społeczne nastawione na pozyskiwanie funduszy w celu utrzymania się przez wnioskodawców. Mimo to na Ukrainie cały czas rośnie liczba dobrze wykwalifikowanej kadry uniwersyteckiej, która nie tyle korzysta w praktyce z historii mówionej, ile czyni pewien namysł metodologiczny nad uprawianą metodą pracy ze źródłem mówionym.

Właśnie w kontekście pracy zawodowej tych badaczy i w czasie trwania drugiego etapu w dziejach historii mówionej na Ukrainie udało się ustalić priorytety tematyczne nowej dyscypliny w tym kraju. Przede wszystkim warto mieć na uwadze, że ich dobór stał się skutkiem tego, że historia mówiona na Ukrainie musiała przez długi okres stawiać czoło wyzwaniom historiografii postsowieckiej, a zatem zamykała się w obrębie badań nad zagadnieniami wcześniej zideologizowanymi, analizowanymi w sposób jednostronny czy też dotychczas zabronionymi tematami oraz bohaterami. Wobec tego w czołówce najbardziej pożądanych tematów znalazły się te, które dotyczyły studiów nad Holocaustem, „nieznanymi ofiarami” i „zapomnianymi bohaterami” w dziejach II wojny światowej ${ }^{10}$, kolektywizacją i klęską Wielkiego Głodu z lat 3o. XX w. ${ }^{11}$, masowych przesiedleń wewnątrz ZSRS i związanymi z nimi kwestiami

10 Np.: Nevigadane. Usnì istorï ostarbajterìv, avtor-uporâd., red., vstup. st. G.G. Grìnčenko, Harkìv 2004; Kniga pam‘âtì Drobickkogo Âru. Spogadi, narisi, dokumenti, avt.-uklad. V.P. Lebedeva, P.P. Sokol's'kij, Harkì 2004; Po tu storonu vojny. Kniga Pamâti žertv nacistskih presledovanij v gody Vtoroj mirovoj vojny, avt.-sost. N. Mihajlov, N. Kuzmenko, Zaporože 2005; My pobedili smert: Vospominaniâ har'kovčan - byvših uznikov fašistskih konclagerej, L'vov 2005; Žizn'i smert'vêpohu Holokosta. Svidetel'stva i dokumenty, kn. 1-3, red.-sost., avt. predisl. i komment. B. Zabarko, Kiïv 2006-2008; T.V. Pastušenko, Ostarbajteri z Kï̈vŝini. Verbuvannâ, primusova pracâ, repatriaciâ (1942-1953), Kiïv; eadem, Vïzd repatriantiv do Kiêva zaboroneno...”. Povoênne žittâ kolišnih ostarbajterìv ta vijs'kovopolonenih v Ukraïnì, nauk. red. O. Lisenko, Kiïv 2011 i wiele innych pozycji.

11 Np.: Ukraïns'kij golokost: Svidčennâ tih, hto viživ, uporâd. o. Û. Micik, L. Ivannìkova, t. I-VI, Kiï 2003-2010; „Stolicâ vidčaû”. Golodomor 1932-1933 rr. na Harkivŝini vustami očevidcìv. Svidčennâ, kommentarì, upor. T. Polîsuk, Harkìv-N'û-Jork-Livìv 2006. 
readaptacji czy resocjalizacji ${ }^{12}$, oraz różnego rodzaju form prześladowania ludności przez władze komunistyczne - mając m.in. na uwadze represje na tle narodowym i religijnym różnego rodzaju grup wewnątrz społeczeństwa sowieckiego ${ }^{13}$. Wraz z tragiczną kartą doświadczenia czasów komunistycznych na Ukrainie, w polu zainteresowań badaczy ukraińskich znalazła się również historia kobiet. Niech też wolno mi będzie zauważyć, że oba te nurty na Ukrainie zyskały na popularności w tym samym czasie, a metodologia historii mówionej pozostaje nadal bardzo popularna wśród badaczy historii kobiet ${ }^{14}$. To samo zresztą można powiedzieć o historii życia codziennego ${ }^{15}$. Tu głównie badacze skupiają się na poznaniu „codzienności wojennej” i „codzienności sowieckiej”. W badaniach nad mniejszościami etnicznymi oraz badaniami poszczególnych warstw społecznych historia mówiona przybiera czasami maskę tradycyjnych badań etnograficznych ${ }^{16}$. Z historii mówionej

12 Np.: G. Vinogradskka, Deportacï̈ ukraïncìv z Polsìi 1944-1947 rr. Problemi periodizacï ta obstavini pereselennâ (za materialami usnih opovidej deportovanih), „Shìd Zahìd. Ìstoriko-kul'turologìčnij zbìrnik" 20o8, vip. 11-12: Usna istorìa v sučasnih social'no-gumanitarnih studiâh. Teorîa i praktika doslidžen', red. V. Kravčenko, G.G. Grìnčenko, s. 243-25o.

13 Np.: S. Gurkìna, Dvi doli. Greko-katolic'ke duhovenstvo ì radâns'ka vlada, „Shìd Zahìd. İstoriko-kul'turologì̌nij zbìrnik” 20o8, vip. 11-12, s. 265-282.

14 Np.: Usna žinoča istorîa. Povernennâ. İstoriografîa sil's'kih žinok $v$ kontekstì suspil'no-istoričnih faktorìv radâns'kogo ì perehidnogo perìdìv, Kiïv 2003; İstorîa odniêï fotografï. Sproba samoprezentacï̈, uporâd., red., vstup. st. G.Ì. Dacûk, Kiïv 2007; O. Kìs', Recepciâ radâns'koï vladi ta nezaležnostì v avtobiografičnih opovidâh žinok Ukraïni (za materialami proektu „Ukraïna XX stolittâ u pam'âtì žinok”), „Shìd - Zahìd. İstoriko-kul'turologìčnij zbìrnik” 20o8, vip. 11-12, s. 283-307; eadem, Kolektivna pam'ât'ta istorična travma. Teoretičnì refleksï na tli žinočih spogadì pro Golodomor, [w:] U pošukah vlasnogo golosu. Usna istoriâ âk teoriâ, metod ta džerelo. Zbìnik naukovih statej, red. G.G. Grìnčenko, N. Hanenko-Frìzen, Harkìv 201o, S. 171-191.

15 Np.: T.V. Pastušenko, Budni ukrä̈ns'kih „ostarbajterìv”. Borot'ba za viživannâ (na materialah spogadiv kolišnih primusovih robitnikì), „Ukraïns'kij ìstoričnij žurnal” 2005, No, s. 160-176; Eadem, Sposobi viživannâ ukraïns'kih ostarbajterìv u Rajhu. Spogadi očevidcìv, „Shìd - Zahìd. İstoriko-kul'turologìcnij zbìrnik” 2008, vip. 11-12, s. 161-179; T. Lapan, Usni istorï galičan-ostarbajterìv. Specifika primusovogo dosvidu, „Shìd - Zahìd. İstoriko-kul'turologìcnij zbìrnik” 20o8, vip. 11-12, s. 198-223.

16 Np.: Û. Ìrìoglu, Usni narativi âk džerelo $z$ istorï bolgars'kogo naselennâ Pìvničnogo Priazov'â XX stolittâ. Avtoref. dis. kand. ist. nauk, Kiïv 2009. 
pełnymi garściami czerpie również historia miast ${ }^{17}$. W zgłębianiu tych tematów wiodącą rolę odgrywają projekty, które były realizowane przy szkołach wyższych oraz przez centra i laboratoria zajmujące się przede wszystkim historią mówioną (powstały na Ukrainie z początkiem XXI w.). Zakres działalności ośrodka lwowskiego i zaporoskiego omówiłam już wcześniej. Wydaje mi się, że wartymi uwagi są również dokonania na polu historii mówionej przez badaczy skupionych przy Edukacyjno-Naukowym Centrum Historii Mówionej przy Katedrze Historii i Kultury Ukrainy w Szkole Wyższej „Perejasław-Chmielnicki Państwowy Uniwersytet Pedagogiczny im. Hryhorija Skoworody" (Navčaĺno-naukovij centr usnoï ìstorìi kafedri ìstorìi ta kuĺturi Ukraïni DVNZ „Pereâslav-Hmeĺnićkij deržavnij pedagogìčnij unìversitet ìmenì G. Skovorodi”) oraz laboratorium edukacyjne „Centrum Historii Mówionej" (Centr usnoï ìstorìi) przy Zakładzie Najnowszej Historii Ukrainy Kijowskiego Narodowego Uniwersytetu im. Tarasa Szewczenki. Oba te ośrodki nie dość, że prowadzą zaawansowane badania z historii regionalnej, to również organizują konferencje naukowe, spotkania warsztatowe czy zjazdy dla członków ukraińskiego Narodowego Towarzystwa Historii Mówionej.

Rzeczą, której nie mogę pominąć, omawiając stan historii mówionej na Ukrainie, jest kwestia prezentacji efektów badań przez poszczególne ośrodki czy też poszczególnych badaczy. Środowisko ukraińskich badaczy wprawdzie zdaje sobie sprawę z istnienia całego wachlarza nowoczesnych form dokumentowania wyników badań, jednakże w dalszym ciągu publikują wyniki swoich badań poprzez tradycyjne monografie, zbiory esejów czy zbiory przetranskrybowanych i adoptowanych do szerszego koła odbiorców zbiorów wspomnień. Tu gwoli ścisłości warto mieć świadomość, że różnorodność w obrębie tradycyjnych form prezentacji zależy od tego, jakie cele stawiał sobie na początku badacz lub zespół badawczy, oraz od różnic podejścia do tworzenia na podstawie relacji świadków narracji o przeszłości występujących w różnych środowiskach akademickich i pozaakademickich. Wszystko

17 Np.: Eine neue Gesellschaft in einer alten Stadt. Erinnerung und Geschichtspolitik in Lemberg anhand der Oral History / Nove suspil'stvo v davnomu mistì. Pam'at' ta istorična politika zasobami oral history, red. L. Henke, G. Rossolinski, Ph. Ther, Wrocław 2007; G. Bodnar, Lviviv. Sodenne žittâ očima pereselencìv iz sil (50-8o-tì roki XX st.). Monografiâ, Livì 2010. 
tu będzie zależało od intencji i decyzji badacza: czy opatrzy tekst aparatem krytyczno-naukowym, czy doda jedynie konieczne komentarze?; czy opublikuje surowe transkrypcje, czy adaptowane do języka literackiego?; czy będzie chciał rozpatrywać historię w skali mikro, przez pryzmat jednej bądź kilku opowieści biograficznych, czy w skali makro, badając procesy i zjawiska w przeszłości?; jakie będą proporcje między miejscem zarezerwowanym dla „głosu badacza” a miejscem przydzielonym dla „głosów rozmówców"?; a w końcu, kim będzie czytelnik jego książki? ${ }^{18}$

Wśród popularnych w historiografii ukraińskiej sposobów konstruowania narracji historycznej w oparciu o historie mówione jest przede wszystkim metoda analizy krzyżowej, w którym narracja staje się podstawowym źródłem wiedzy i tworzywem do kształtowania wiedzy na temat przeszłej rzeczywistości oraz kreowania jej obrazów ${ }^{19}$. Określenie „konstruowanie" dotyczy tu analizy historii mówionych i określa sposób postępowania z materiałem narracyjnym, w którym treść wywiadu jest tworzywem do odtworzenia określonej sytuacji, wydarzenia czy środowiska. Innymi słowy badacz w procesie „konstruowania” dąży do ustalenia, jak zmienia się w perspektywie historycznej kontekst społeczny oraz jego poszczególne elementy. W tym podejściu informacja zaczerpnięta $\mathrm{z}$ narracji zostaje „wpleciona” w szersze tło wykreowane na podstawie informacji z innych źródeł, co w zasadzie stanowi istotę tego typu pracy ze źródłem. W ramach takich badań rzeczą drugorzędną jest forma, którą narrator nadaje swojej opowieści oraz tematy, które zdaniem narratora są ważne. Całość bowiem zostaje podporządkowana badaczowi, który ma określone zadania badawcze. Podejście to sprawdza się głównie w pisaniu monografii, gdyż w publikowanych zbiorach wspomnień retoryka będzie miała zupełnie inny charakter, zwłaszcza gdy chodzi o balansowanie między tym, co „obiektywne”, a tym, co „subiektywne”.

$18 \mathrm{Na}$ temat najpopularniejszych sposobów budowania narracji historycznej na podstawie świadectw ustnych zob.: P. Thompson, Golos prošlogo. Ustnaâ istoriâ, Moskva 2003, s. 268-270. O zasadach klasyfikacji i „gatunkach” historii mówionych zob.: A. Portelli, Oral History as Genre, [w:] Narrative and Genre. Namysł teoretyczny dotyczący wielu problemów i możliwości publikowania historii mówionych zob. również: Handbook of Oral History, ed. Th.L. Charlton, L.E. Myers, R. Sharpless; with the assistance of L. Roy Ballard, Lanham, MD 2006.

19 P. Thompson, op. cit., s. 269. 
W moim przekonaniu, odpowiednim przykładem takiego typu pracy ze źródłem mówionym jest praca Tatiany Pastuszenko, dotycząca losów robotników przymusowych z Kijowszczyzny pracujących na terenie hitlerowskich Niemiec ${ }^{20}$. Badaczka skupiła się głównie na przestudiowaniu zasad werbunku i etapów deportacji na roboty, sytuacji społecznej ostarbajterów na terenie Rzeszy oraz sposobach radzenia sobie w sytuacji granicznej. W zasadzie historie mówione umożliwiły autorce realizację zadania postawionego we wstępie: „przesunąć punkt ciężkości z badania makro struktur społecznych na robotnika nie jedynie jako podmiotu i przedmiotu działań ze strony władz, lecz na samodzielnego aktora historii, rozpatrzyć sposoby radzenia sobie w trudnej sytuacji życiowej jednostki jako zespół zachowań wynikający z kontekstu społecznego; wyjaśnić, czy były możliwości wyłamania się ze schematu zachowań narzuconych przez okoliczności, w których znaleźli się robotnicy przymusowi w Niemczech i jeśli tak, to jakie to były zachowania?"21.

W ten sam sposób źródła narracyjne zostały wykorzystane w pracy Hałyny Bodnar pt. Lwów. Życie codzienne w oczach migrantów $z$ wsi do miasta w latach 50.-8o. $X X w^{22}$ Badaczka bowiem sięgnęła po narracje ustne, aby oprócz danych statystycznych zarysować szerszy społeczny kontekst związany z migracjami ze wsi do miasta. W polu jej zainteresowań badawczych znalazły się zatem: kwestie mieszkaniowe i adaptacyjne w nowym miejscu zamieszkania, edukacja i zatrudnienie, życie społeczno-polityczne i kulturowe powojennych mieszkańców Lwowa.

Innym sposobem pracy ze źródłem mówionym jest podejście określane przez współczesnych badaczy jako narratywistyczne czy też tekstuologiczne, które zakłada, że przedmiotem analizy nie są fakty, lecz sama opowieść. Specyfika tych badań polega na przyglądaniu się źródłu od strony tekstowej, a więc badane są: język, tematy i fabuła, kolejność przywoływania poszczególnych wątków. Sposób ten, polegający na przyjrzeniu się temu, jak rozmówca doświadczył przeszłość, jak ją zapamiętał i w jaki sposób ją odtwarza w narracji, spotykany jest bardzo rzadko, ale jest kluczowy do badań nad pamięcią kulturową i komunikatywną określonej społeczności oraz jej tożsamości. Osobiście jestem zwolenniczką właśnie takiego podejścia.

20 T.V. Pastušenko, Ostarbajteri z Kï̈vŝini...

21 Ibidem, s. 28-29.

22 G. Bodnar, op. cit. 

musu do pracy: metodologia, kontekst $i$ tekst ${ }^{23}$, były narracje robotników przymusowych z Ukrainy, które rozpatrywałam jako opowieści. Analizując je w nadanym im przez rozmówców kształcie i ich subiektywnym charakterze, zdołałam dostrzec i wyodrębnić wspólne dla nich cechy pod względem formy wypowiedzi oraz ich treści, a także przyjrzeć się logice rekonstruowania opowieści o doświadczeniu robót przymusowych czy też intencjom narratorów co do stworzenia określonej wizji własnej przeszłości. Jednakże pod względem kompozycyjnym studium to wychodzi znacznie poza ramy wyłącznie analizy tekstu. Przeanalizowane historie mówione umieściłam w dwu zasadniczych kontekstach, które pomagają zrozumieć wywiad biograficzny. Pierwszym z nich jest fakt historyczny robót przymusowych milionów obywateli sowieckich w trakcie II wojny światowej (kontekstualizacja nabytego doświadczenia), drugim zaś - różne formy prezentacji tego doświadczenia w przestrzeni publicznej postsowieckiej Ukrainy (kontekstualizacja odtwarzanego doświadczenia).

Pozostaje jeszcze trzeci i zarazem najbardziej popularny sposób traktowania źródeł mówionych przez badaczy ukraińskich, a w zasadzie również przez badaczy z byłych republik związkowych - publikacja zbiorów opowieści biograficznych bądź tematycznych, ale opartych na biografiach tzw. zwykłych ludzi, gdzie „nie są istotne bogactwo czy głębia, konieczne do szczegółowej opowieści ważne jest bowiem ukazanie typowości materiału"24. W tych pracach głos decydujący należy do rozmówców, rola badacza ogranicza się jedynie do edycji i opatrzenia tekstów prostym i czytelnym komentarzem zawierającym jedynie elementy analizy przytaczanych wspomnień. Zawarta we wstępie takiej książki oklepana formułka „celem niniejszej książki jest dopuścić do głosu tych, którzy...” absolutnie nie wyklucza twórczej pracy w trakcie jej powstawania, wszak to badacz decyduje o doborze wywiadów, ich ostatecznym kształcie, proporcjach między ilością wstępu a liczbą przytaczanych opowieści, jak również o tym, do jakiego kręgu czytelniczego zostanie ona zaadresowana ${ }^{25}$. W ten sposób to od badacza zależy, które opowieści wejdą do tomu, w jaki sposób zostaną podzielone na grupy, jaki wspólny mianownik zostanie im nadany.

\footnotetext{
23 G. Grìnčenko, Usna istorîa primusu do praci. Metod, konteksti, teksti, Harkìv 2012.

24 P. Thompson, op. cit., s. 268.

25 Dokładniej zob.: A. Portelli, op. cit.
} 
W środowisku badaczy historii mówionej na Ukrainie królują dwa zasadnicze sposoby prezentowania świadectw: monolog albo kolaż, przy czym w obu przypadkach elementem scalającym narracje może być zarówno narzucony przez badacza porządek chronologiczny, jak i logiczny (logicznie lub chronologicznie poukładany chaos narracji biograficznej).

Jako przykład pierwszego sposobu prezentacji historii mówionych proponuję rozpatrzyć dwie książki: Historia mówiona kobiet. Powrót: Historiografia wiejskich kobiet w kontekście społeczno-historycznych czynników $w$ czasach sowieckich $i$ w okresie transformacji ustrojowej ${ }^{26}$ oraz Dzieje jednego zdjęcia: próba autoprezentacji ${ }^{27}$. Wydawcą obu tych książek jest ośrodek „Dziedzictwo”. W pierwszej z nich umieszczono opowieści kobiet mieszkających na obszarze całej Ukrainy w wieku 70-9o lat, które doświadczały wydarzeń przełomowych w swoim życiu w czasach sowieckich oraz w okresie transformacji systemowej. W drugiej natomiast umieszczono opowieści kobiet, które aktywnie działały w formacjach OUN-UPA w trakcie II wojny światowej i które przez całe życie pozostały patriotkami swojego kraju, aktywnie działając w przestrzeni społecznej i publicznej. Obie te książki są wyjątkowe, dlatego że w odróżnieniu od zdecydowanej większości dzieł spod tego znaku opowieści nie są dobrane w kolekcję podporządkowaną określonej tematyce, określonemu wydarzeniu w życiu narratorów. Jest to w obu przypadkach zbiór narracji biograficznych z prawdziwego zdarzenia.

Przykładem kolażu jako sposobu prezentowania opowieści w ramach publikacji zbiorowej jest książka Szrama przez całe życie. Wspomnienia ukraińskich robotnic przymusowych $z$ Nadrenii ${ }^{28}$. Publikacja ta składa się z opowiadań dziesięciu kobiet, w których życiu doświadczenie pracy przymusowej w Niemczech pozostawiło znaczący ślad. Nie można oczywiście zakwestionować wyjątkowego charakteru wszystkich opisanych historii, jednakże wspólnym przesłaniem, które przewija się między słowami każdego z opowiadań, jest stwierdzenie, że „dla większości [kobiet] powrót do ojczyzny nie oznaczał powrotu do normalnego życia w tym rozumieniu, które temu pojęciu nadawali ich rodacy w kraju. Bezdzietność, późne i za-

26 Usna žinoča ìstoriâ. Povernennâ...

27 İstorîa odniêï fotografï...

28 Trìsina krìz'use žittâ. Spogadi ukraïns'kih primusovih robìtnic'v zemli Rajnland. Katalog do vistavki, K'ol'n 2007. 
razem krótkie zamążpójście oraz samotna starość czekały na kobiety, oczekujące zupełnie innego losu po powrocie do ojczyzny"29.

W tym miejscu też chciałabym odnieść się do trzech innych opracowań wspomnień robotników przymusowych ${ }^{30}$. Zostały one skomponowane tak, aby czytelnik miał możliwość zapoznania się z różnorodnymi, a czasem nawet zgoła odmiennymi opiniami i sprzecznymi refleksjami o podobnym doświadczeniu biograficznym u różnych rozmówców.

Wydawać by się mogło, że rola badacza w wydaniu źródeł narracyjnych sprowadza się wyłącznie do „pomysłu na zrobienie książki”, tymczasem od niego właśnie zależy, w jakim kontekście tematycznym zostaną umieszczone poszczególne narracje (background) ${ }^{31}$. Tego typu kontekstem są zazwyczaj komentarze albo odnośniki redaktorskie, którymi zostaje opatrzony przetranskrybowany wywiad; wszelkie wstępy, wprowadzenia, zakończenia i epilogi do całości zbioru; krytyczny artykuł badacza umieszczany przed pierwszą narracją czy przed każdym rozdziałem tematycznym. Można do tego typu kontekstów odnieść pozostałe teksty (nie narracje świadków) jednocześnie zawarte w zbiorze dokumentów i materiałów do dziejów jakiegoś wydarzenia historycznego. W taki sposób został skomponowany np. zbiór wywiadów pt.: „...To była niewola”. Wspomnienia i listy ostarbajterów ${ }^{32}$.

Z drugiej też strony artykuły wprowadzające do opracowań zbiorowych mogą mieć przecież kształt sprawozdań z realizowanego projektu (w ramach którego te publikowane w zbiorze opowieści nagrano), jak również mogą w nich się znaleźć informacje dotyczące sposobu opracowywania tego zbioru, zasady wedle których zostały dobrane tu poszczególne narracje oraz zasady zastosowane przy edycji tekstu oraz jego segmentacji na poszczególne wątki. Zabiegi te pozwalają czytelnikowi dowiedzieć się, co traci i co zyskuje, czytając publikację w takiej, a nie innej postaci. Artykuły te mogą też mieć postać informacji historycznej wprowadzającej czytelnika

29 Ibidem, s. 21.

30 Nevigadane. Usni istorï...; „Prošu vas mene ne zabyvati”. Usnì istorï ukrä̈ns'kih ostarbajterìv, [G. Grìnčenko et al.], Harkìv 2009; Malen'kì lûdi na velikì vìjni. Usnì istorï̈ ostarbajterìv ta v'âznìv konctaborìv z Poltavŝini, upor. V. Lahno, vìdp. red. Û. Vološin, Poltava 2011.

31 A. Portelli, op. cit.

32 „...To byla nevolâ”. Spogadi ta listi ostarbajterìv, Kiïv 2006. 
w tło omawianych przez narratorów wydarzeń ${ }^{33}$ albo i luźno powiązanych ze sobą refleksji na temat potencjału historii mówionych jako przedmiotu badań we współczesnej humanistyce ${ }^{34}$.

Reasumując sytuację historii mówionej na Ukrainie, która ukształtowała się na chwilę obecną w historiografii ukraińskiej, warto podkreślić state of affairs w tej dyscyplinie badawczej. Po pierwsze, w przestrzeni tematycznej współczesne badania w duchu historii mówionej z sukcesem balansują na intelektualnym pograniczu oficjalnych projektów z historiografii narodowej i nieoficjalnych dyskursów prywatności, życia codziennego jednostki. Współcześni badacze są zatem zainteresowani w równym stopniu zarówno problemami o wadze narodowej (tematy priorytetowe dla oficjalnej historiografii narodowej i powszechnie obecne w dyskursie publicznym), jak i dotyczącymi mikrohistorii jednostek, grup czy społeczności, które mieszkają w niedużych skupiskach i mają podobne doświadczenie udziału w jakichś wydarzeniach albo łączy ich przynależność społeczna, religijna lub etniczna. Przy czym zauważalne jest ukierunkowanie historii mówionej wciąż na jedno z pierwszych haseł: przywrócić albo oddać głos tym wszystkim, których doświadczenie i historie życia w czasach sowieckich były zapomniane, niepopularne albo zabronione. Celem historii mówionej jest przekaz doświadczenia następnym pokoleniom i jego nagłośnienie w przestrzeni publicznej. Poszerzenie tematyki historii mówionej w kierunku badań po prostu interesujących historii dopiero nadejdzie.

Po drugie, ukraińska historia mówiona na dobrze zagościła w środowisku międzynarodowym, o czym świadczy udział ukraińskich badaczy w licznych, branżowych, międzynarodowych konferencjach naukowych (a zwłaszcza w spotkaniach Międzynarodowego Stowarzyszenia Historii Mówionej), wspólnych inicjatywach, publikacjach, realizowanych wspólnie projektach badawczych i edukacyjnych. Wśród najbardziej rozpoznawalnych projektów międzynarodowych z udziałem badaczy z Ukrainy warto wymienić: projekt dokumentacji świadectw osób, które w trakcie II wojny światowej były robotnikami przymusowymi na terenie III Rzeszy (pomysłodawca i koordynator: niemiecka fundacja „Pamięć, Odpowiedzialność

33 G. Grìnčenko, T. Pastušenko, Ukrä̈ns'ki ostarbajteri nacists'koï Nimeččini. Deportaciâ, primusova pracâ, repatriaciâ, [w:] „Prošu vas mene ne zabyvati”..., S. 9-56.

34 G. Grìnčenko, Usna istorìa - teorìa, metod, džerelo, [w:] Nevigadane. Usnì istorï̈..., S. $10-32$. 
i Przyszłość) ${ }^{35}$; projekt „Pamięć kobiet” („Žìnoča pamât””, pomysłodawca i koordynator: Centrum Studiów Genderowych w Pradze) ${ }^{36}$; oraz realizowane w latach 2010-2012 wspólne niemiecko-polsko-ukraińskie projekty „Pamięć i Zapomnienie. Społeczno-kulturowe zmiany w powojennym Jugowie” („Pamât ta zabuttâ. Socìokul turnì zmìni u povoênnomu Ûgovì (Gausdorfì), Sovinì gori”) ${ }^{37}$ i „Stacja kolejowa Krasne-Busk. Opowieści przesiedlonych kobiet” („Krasne - vuzlova stanciâ pereselen”) ${ }^{38}$. Wśród bilateralnych projektów z historii mówionej należy wymienić w pierwszej kolejności ukraińsko-białoruski projekt „Transformacja codziennych praktyk adaptacyjnych: sowiecki i postsowiecki okres. Białoruś - Ukraina” („Transformaciâ povsâkdennih adaptivnih praktik: radânśkij/postradânśkij perìodi. Bìloruś, Ukraïna”, organizator: Instytut Narodowej Akademii Nauk Białorusi, Białoruski Uniwersytet Państwowy w Mińsku, Odeski Narodowy Uniwersytet) oraz ukraińsko-kanadyjski projekt „Historia mówiona dekolektywizacji na Ukrainie w latach 9o. ubiegłego wieku. Doświadczenie mieszkańców wsi” („Usna ìstorìa dekolektivìzacii v Ukraïnì 1990-h rr. Selânś kij dosvìd”) a także polsko-ukraiński projekt „Pojednanie przez trudną pamięć Wołyń 1943” („Poêdnannâ čerez važku pamât. Voliń 1943”) ${ }^{40}$ i wiele innych. Warto zaznaczyć, że wiele prywatnych inicjatyw z historii mówionej, realizowanych przez ukraińskich badaczy, otrzymywało wsparcie finansowe od wielu międzynarodowych fundacji i agencji finansujących badania na Ukrainie, m.in. Amerykańska Rada Towarzystw Naukowych (ACLS), fundacja Gerdy Henkel (Gerda Henkel Stiftung), Fundacja „Pamięć, Odpowiedzialność i Przyszłość” (Die Stiftung „Erinnerung, Verantwortung und Zukunft”) oraz Centrum CASE (The Center for Advance Studies and Education).

35 Zob. publikację wyników projektu: Hitler's Slaves. Life Stories of Forced Labourers in Nazi-Occupied Europe, ed. A. von Plato, A. Leh, Ch. Thonfeld, New York 2010.

36 http://www.womensmemory.net/ (dostęp: 28 IV 2013).

37 http://www.geschichtswerkstatt-europa.org/expired-project-details/items/ hausdorf.html (dostęp: 28 IV 2013).

38 http://www.geschichtswerkstatt-europa.org/project-details/items/krasne.html (dostęp: 28 IV 2013).

39 N. Hanenko-Frìzen, Usna istorîa dekolektivizacï v Ukraïnì 199o-h rr. Sel'âns'kij dosvid, „Shìd - Zahìd. İstoriko-kul'turologìčnij zbìrnik” 20o8, vip. 11-12, s. 370376.

40 Pojednanie przez trudną pamięć - Wołyń 1943, pomysł, wybór, red. A. Zińczuk, Lublin 2012 . 
Oprócz doświadczenia wymiany myśli i podtrzymywania kontaktów naukowych wynikiem intensywnej integracji uczonych z Ukrainy z międzynarodową wspólnotą badaczy historii mówionej stały się również zmiany w stosowanej metodologii - przede wszystkim chodzi o odejście od patrzenia na historię mówioną jedynie jak na źródło faktów lub informacji ukrytych albo przemilczanych przez oficjalną historiografię - jak również i ukierunkowanie zainteresowań badawczych w kierunku studiów nad pamięcią i subiektywnym doświadczeniem, a w szerszym znaczeniu przeniesienie pamięci w centrum zainteresowań badaczy historii mówionej jako przedmiotu badań, nie zaś jako metody ${ }^{41}$. Ta wymiana doświadczeń sprzyjała uświadomieniu tego, że krytykowana przez historyków-pozytywistów wadliwość pamięci jest jednak jej zaletą, a subiektywny charakter wspomnień jest kluczem do zrozumienia nie tylko znaczeń doświadczenia historycznego, ale i pomaga zrozumieć relacje między przeszłością a współczesnością, między wspomnieniem a tożsamością jednostki, między pamięcią indywidualną a pamięcią zbiorową ${ }^{42}$. W związku z tym warto podkreślić jeszcze kolejną cechę charakterystyczną realizowanych projektów naukowych z historii mówionej. Chodzi o użycie historii mówionej do poszukiwania możliwości pojednania i wypracowania wspólnego fundamentu wzajemnego zrozumienia pomiędzy państwami o trudnym doświadczeniu w nie tak odległej przeszłości, jak np. wspominany już projekt o wojennych losach mieszkańców Wołynia.

Już zupełnie na koniec pragnę dodać, że społeczność akademicka badaczy historii mówionej na Ukrainie na chwilę obecną określiła się pod względem instytucjonalnym i dyscyplinarnym. Od 2006 r. istnieje na Ukrainie Narodowe Towarzystwo Historii Mówionej (Nacìonaĺna asocìaciâ usnoï ìstoriii $)^{43}$, którego zadaniem jest organizowanie konferencji międzyna-

41 W tym okresie ukazały się dwa numery tematyczne ukraińskich czasopism naukowych, poświęcone wyłącznie teorii i praktyce historii mówionej: „Ukraïna moderna” 2007, č. 11; „Shìd - Zahìd. İstoriko-kul'turologìčnij zbìrnik” 20o8, vip. 11-12.

42 A. Tomson, Čotiri zmìni paradigm v usnì istorï̈, „Shìd - Zahìd. İstoriko-kul'turologìčnij zbìrnik" 2008, vip. 11-12, s. 9.

43 T.V. Pastušenko, Do stvorennâ Ukrä̈ns'kö̈ asociacï usnö̈ istorï, „Ukraïns'kij ìstoričnij žurnal” 2007, No 3, s. 230-235; G.G. Grìnčenko, Mižnarodna konferenciâ „Usna istorìa $v$ sučasnih socialno-gumanitarnih studîa. Teorîa i praktika doslidžen” ta stvorennâ Ukraïns'koï Asociacï Usnö̈ İstorï, „Shìd - Zahìd. İstorikokul'turologì̀̌nij zbìrnik" 20o8, vip. 9-10: Patria, red. V. Kravčenko, s. 413-415. 
rodowych oraz wydawanie publikacji o tematyce dotyczącej historii mówionej $^{44}$ oraz okazanie wsparcia innym projektom wydawniczym ${ }^{45}$. Cały szereg wydziałów humanistycznych na ukraińskich uczelniach dodaje do programów nauczania zajęcia z historii mówionej ${ }^{46}$. Począwszy od pierwszego dziesięciolecia XXI w. coraz częściej zaczęły się pojawiać rozprawy na stopień pisane w oparciu w całości lub w dużej mierze o źródła narracyjne $^{47}$. W moim przekonaniu przytoczone argumenty przemawiają za tym, że historia mówiona na Ukrainie, z jednej strony, jest realizowana na bardzo wysokim poziomie merytorycznym, z drugiej zaś, jest popularnym narzędziem historiografii do stworzenia tzw. history from below, jak również sposobem na przewartościowanie historii czasów totalitarnych oraz indywidualnego doświadczenia historii - ważnych ze społecznego i kulturowego punktu widzenia wydarzeń.

Tłumaczenie z języka ukraińskiego Wiktoria Kudela-Świątek

44 „Shìd - Zahìd. İstoriko-kul'turologičnij zbìrnik” 20o8, vip. 11-12; International Scholarly Symposium "In Search of Voice. Oral History as Theory, Method, and Source". Conference Program and Proceedings. Kharkiv, 11-12 December 2009, Kharkiv 2009; U pošukah vlasnogo golosu...; „Vìsnik Kiïvs'kogo nacìonal'nogo unìversitetu ìmenì Tarasa Ševčenka. İstorìâ" 2012, vip. 111.

45 Malen'ki lûdi na velikij vìnì...

46 Zob. np. program kursu „Historia mówiona”: http://www-history.univer.kharkov. ua/filez/UsnaIstoriyaTeoriyatapraktyka.pdf; http://www.sociology-lnu.org.ua/Navchannia/Opysy_navch_kursiv/kurs_spec_Usna_ist_yak_metod_reconstr.htm (dostęp: 28 IV 2013).

47 Np.: T.D. Lapan, Verbuvannâ i deportaciâ naselennâ Ukrä̈ni do Nimeččini ta umovi jogo praci i pobutu u nevoli). Avtoref. dis. kand. ist. nauk, Lvìv 2001; T.V. Pastušenko, Ostarbajteriz Ukraïni. Verbuvannâ, primusova pracâ, repatrìaciâ (istoriko-social'nij analiz na materialah Kiïvŝini). Avtoref. dis. kand. ist. nauk, Kiïv 2007; Û. İrìoglu, op. cit.; G.G. Grìnčenko, Ukraïns'kì ostarbajteri v sistemì primusovoï pracì Tret'ogo rajhu. Problemi istoričnoï pam'âtì. Avtoref. dis. d-r ist. nauk, Kiïv 2011. 
Gelinada

Grinczenko

Oral History in Ukraine: people, topics, facts
This article is about the situation in Ukraine, which allowed oral history to develop unrestrainedly in the post-Soviet period. The author distinguishes and analyses the development stages of this research approach and defines its distinctive features. Considerable attention is also paid to the analysis of numerous methodological strategies that were used by Ukrainian researchers to write papers based on oral history. The author also mentions numerous national and international projects organised by, or carried out with the participation of Ukrainian researchers. Furthermore, the research subjects undertaken by Ukrainian researchers have been ranked in order of priority. An institutional status is also described, along with the main trends and tendencies in the development of this research approach in Ukraine, which is also shown. 